УДК 1:[316.7:316.324.8]

NIKITENKO, VITALINA

$\mathrm{PhD}$ in Philosophy, Assistant professor of the Department of foreign languages and linguistic communication, Zaporizhya Engineering Academy (Zaporozhye, Ukraine) E-mail: vitalina2006@ukr.net

\title{
CULTURAL AND SOCIAL COMPETENCE CREATION IN THE PROCESS OF ENGLISH LANGUAGE STUDY: INFORMATION SOCIETY ASPECT
}

The present article analyzes the foreign language teaching approaches in the studying process of social and cultural sciences such as social philosophy, political science, cultural studies, psychology, sociology, history and others that possess a number of units and structural elements of the social and humanitarian sciences; The article defines the importance of facing to the cultural and geocultural values during the foreign languages studying and reveals its significance. Each of the above sciences studies the specific features of geoculture which can extend our knowledge by the means of foreign language on the one hand and to master the foreign language with the help of the mentioned subjects from the other hand.

Key words: foreign language, studying process, teaching approaches, geoculture, geoculture of linguistics, structural analysis, language characteristics, information society

Problem definition as a whole and its relationship with important scientific or practical tasks

At present, everyone is put in difficult conditions of social life by the dynamism of controversial world. Growing tensions are associated with changing of orientations, the need to search and quickly find solutions, stress - all the problems of human life, the preservation and development of the individual, his inner world, the formation of the person of socialization spiritual growth, and therefore at the forefront a culture that has a high mission - to solve global problems facing the modern world community. The current stage of development is characterized by contacting a humanist ideas turn to the man, his needs and interests. Training and education of the special qualities of a person confronts science demands of the formation of a person of socialization spiritual growth. Modernity confronts the human need for reasonable, rational and responsible attitude to the world, to his own interests, needs and deeds. Everyone should be able to navigate consciously in reality, to determine the place in society and the world, look for problems of implementation needs and interests. The ability and capability reasonable to think is not generated automatically, they must be fulfilled in the process of social and human sciences and, 
above all, foreign languages and philosophy - theoretically formulated vision systems, the most common theoretical view of the world and man's place in the world, and therefore at the forefront culture, a high mission - to solve global problems facing the modern world community.

Analysis of recent researches and publications where we can observe the beginning of the problem solution

The main objective of the present scientific study is to identify some teaching methods of social and cultural study in the process of foreign languages mastering. To achieve the main goal we have formulated a number of tasks:

languages;

To define the self-development of culture in the study of the foreign

- To reveal the impact of cultural studies on the formation of foreign languages thinking;

- $\quad$ To analyze the psychological studies of culture and geoculture including ethnic psychology;

- To show the role of sociology of culture in the consciousness development in the process of foreign language studying;

- To ground the role of foreign language and geocultural values as unifying in certain social societies and communities;

- To show the role of religion of geoculture including the analysis of world confessional map and the spreading of religious rites and traditions.

The exposition of main material

The foremost is the revival of the public interest to the problem of values, especially to geoculture and geovalues. The persistent consideration of "value" concept with different epithets in mass media (economic, legal, moral, aesthetic, common to all mankind, social and spiritual values) introduced this term generalized in human consciousness. A new access to the global public arena of values problems requires above all rethinking of the basic principles and systemizing the whole knowledge of cultural values[3].

Also, cultural values are carries and spiritual conductors in the field of human consciousness in a reverse way. The actuality of cultural values research is in the fact that they (values) do dissociate human life from just biological existence. A person grasping the difference from other living creatures on Earth realizes himself in values as vital aims and ideals.

In addition we should note that exactly values determine the sense of human existence as they are the core of internal and external culture and society. Therefore, investigating geoculture axiologically we should speak not of the "culture" definition but seek only a meaningful base of the semantic core - geovalues. According to common agreement of global society, they are the cores of a new information civilization which are the true human spiritual values, such as faith, hope, love and consciousness. When defining a central science notion "value" we should remember of "elusiveness". Culture as a set of ideas about values and ideals is not limited by 
one social life sphere, but is able to cover different areas that regulate various person activities[2].

Firstly, geoculture as a phenomenon originated long ago, but its existence didn't have a total character, because its carriers were separate and even prominent personalities - philosophers or war commanders, such as Alexander Macedonian, Napoleon etc. and only at the beginning of XXI century the process of its forming took great power and began to show up along with ontological, organizational and informative unity of world community.

Secondly, the investigating subject needs the achievements of all abovementioned approaches, because only the integrated knowledge with high measure of authenticity can explain the process of geovalues generation, geocultural functioning and geopolitics, and also promote scientific prediction of future development of the world community in the paradigm of spontaneous integrative and disintegrative processes inherent to modern transformations of the planetary community structure.

Thirdly, the analysis of geoculture scientific approaches proved that it has sensible, valuable, psychological, social and political characteristics that demonstrate value-semantic matrix of planetary life in the space-and-time dimension; it's becoming more visible and more influential on the global human lifestyle. Geovalues - is just one of the natural movements of a sensible living substance[4].

Fourthly, the manifestation strengthening of the phenomenon is observed in the long time-line due to a considerable increase of spatial continuum, and with the growth of globalization tendencies we should expect an aggressive display of its organizational properties in the form of integration-disintegration processes and negative psychological consequences among the localized subjects of cultural and historical processes that are not ready to accept the formation of global civil society, keep their own ethno national values, for example, sharia, do not understand the major trends of community self-development - intellectual energy mastering, cosmopolitan consciousness formation with its adequate life vision and, finally, living outside our planet.

Cultural geography interesting in the process of foreign languages study is quite a young science for our country, and it often comes across non-acceptance, incomprehension overcoming prejudice, particularly by geographers. Cultural geography means much scientifically and practically, as a new humanitarian discipline because it is one of the outstanding geocultural research methods that studies geocultural and geopolitical semantics in the cultural context, the problem of relations of cultural regions and local awareness, the problem of cultural landscape and its components.At the present day cultural geography experiences the stage of break, when the spontaneously formed "amount" of cultural and geographical researches grows into "quality" - a significant theoretical and methodological basis of new geoculture[1].

The first step necessary for geocultural interpretation is a geographical point on 
the world map, and a traditional locality description that may seem out-of-date. Also, a traditional and rather effective means of geocultural determination is wandering, but it demands the highest level of complexity. This great number of interpretations of culture diversity of methods and forms, the means of creative interpretation, the inner and outer contradictions makes it a "perpetuum mobile", giving it the ability to continuous development and mobility.

Let's consider the constituents of geospace by means of hermeneutics. From time immemorial the description of geographical peculiarities of culture has been very popular in this or that form. Each traveler has always considered it necessary to describe the traditions and customs of the land he visited and to observe the difference from his own land and people. In fact, those earliest descriptions were the first geocultural works. Although those works didn't have analytical character but they clearly and vividly revealed the cultural mosaic of our planet.

As already mentioned, the subject of journey description is very popular in modern geoculture, and as a scientific method it is probably the most popular. Present day scientists base their researches and conclusions on travelers' experience that analyze geocultural images. Most likely, as a separate independent science, geoculture was born in XX century at the turn of culturology, geography and geopolitics. The origin of geoculture and its first features can be found in culturological researches. Geoculture is considered to originate firstly from culturology, as the last one could never do without geographical approach. It is obviously, as no other social science paid so much attention to space. Philosophy, sociology and even history easily deepened in abstraction, while cultorology always knew and kept in mind a specific area, because its studies have been tied to definite points, natural habitats and cultural carriers.

The attempt to find territorial binding for all world cultural spaces and choose toponyms that define the location of cultural spaces appeared to be the basis of geographical approach in geoculture. The representatives of this school are such prominent scientists as Spengler, Arnold Toynbee, N.Danilevsky, L.Gumilev. Each of them developed his own theory of cultural geographic zone of the world space. The main representative of anthropological geography school is a prominent German scientist Friedrich Ratzel. The most famous of his works about anthropo-geographical studies are "Ethnology", "Land and life" and "Comparative physical geography" published in Russian language at the beginning of XX century. Friedrich Ratzel was the first to introduce a "human element", i.e. a humanistic element in traditional geographical science. He described a detailed picture of peoples' settlement and culture spreading. The main theoretical basis for the early cultural geography was geographical determinism. It makes no sense to dwell in details on its specifics. But we should note that it was Ratzel who studied cultural diffusion appreciating geographical determinism. Generally speaking, anthropo-geography and cultural diffusion have much in common, namely: 
- Theory of migration which includes the primacy of cultural values movement to multiple independent birth;

- The principle of cultural space continuity, or continuum;

- The conception of "form circles" - the complex of cultural characteristics.

Many scientists, both culturologists and geographer at the beginning of XX century made an accent on the influence of environmental factor on cultural genesis. It was at that time when the terms "cultural ecology" and "human ecology" appeared. The American school of K. Whisler, one of the founders of cultural area concept, works productively in these directions. J.Stort investigates human behavior under the influence of natural forces and environment, studying also the culture of a man in certain localities. There are similar works of such famous geographical determinism followers as Helen Cherchik Semple, Ellsworth Huntington, Albert Perry Bryhhem etc.

But eventually geographical determinism was rejected that caused the birth of cultural geography, and the other reason was the understanding of imperfections of describing approach of cultures spreading. Is cultural geography a social science or humanitarian or any other?

To answer the actual questions we should distinguish base directions of geoculture. But the gradation is rather approximate because of absence of clear determinations. So they are:

1. Determination of cultural groups in space. Here geography of religion, ethnic geography and linguistic geography found their place.

2. Description of different aspects of creative activity of cultural groups. This direction was entered by geography of art, science geography, geography of life culture and geography of mass culture.

3. Study of cultural and geographical aspects within the framework of other geographical sciences. Here we should include geography of economic culture, geography of settlements culture and geography of political culture.

To understand the basic principle of a separate discipline it is necessary first of all to describe it.

To sum it up, in the geographical context of cultural geography it's possible to distinguish a separate direction - geography of cultural groups with substantial constituents of geoculture of religions, ethnic geoculture and geoculture of linguistics.

Geoculture of religion analyzes confessional world maps investigating distribution of religious rites and traditions and complex religious systems. One of the investigating subjects of geoculture of religions is the analysis of religion founders. The aim is to look at the confessional world map without any borders and restrictions. Ethnic culture is the second widest direction of cultural geography. It studies ethnic identity in the context of geography. The most important task is to analyze distribution of ethnic and sub-ethnic groups in order to determine the causes of ethnic conflicts. The founder of ethnic geography is W.Kollmorhen. Geoculture of 
linguistics is direction of geography of culture with its focus on a language and strucural analysis as a basic investigating method. It includes several levels: family language groups, languages themselves, dialects and mode of speech. It is important that they study the distribution of certain language characteristics of one language unit, i.e. phonetics, lexis, syntaxes, spelling etc.

Methods which we may rely on in our research work are varied and their choices depend on what exact task we are to solve. Multidimensionality of investigated phenomena stipulates for interdisciplinary character research based on different general philosophical, scientific and specific methods that interact and determine each other, providing for the validity and authenticity of scientific results.

\section{Список використаної літератури}

1. Воронкова В. Г. Філософія глобалізації: соціоантропологічні, соціоекономічні та соціокультурні виміри: [Монографія] / В.Г.Воронкова. - Запоріжжя: Видавництво ЗДІА, 2010.- 272 c.

2. Базалук О. А. Сущность человеческой жизни: [Монография] / Олег Александрович Базалук.- К.: Наукова думка, 2002.- 270 С.

3. Бех В. П. Человек и Вселенная: когнитивный анализ: [Монография]. - 2-е изд. доп./ В.П.Бех. - Запорожье: Просвіта, 2004. - 148 с.

4. Нікітенко В. О. Проблемне поле геокультурного феномену / В.О.Нікітенко // Гілея (науковий вісник): зб. наук.пр.- К.: Вид-во УАН ТОВ «НВП» «ВІР».- 2013.- Вип.71.- С.500-504.

\section{REFERENCES}

1. Voronkova $V$. G. The philosophy of globalization: the socioanthropological, socioeconomic and sociocultural dimensions. Monograph. / V. G. Voronkova. - Zaporozhye: ZSEA Publishers, 2010. - 272 $p$.

2. Bazaluk O. A. The essence of human life / O. A. Bazaluk. - K . : Naukova Dumka, 2002. - 270 $p$.

3. Bech V. P. Man and the Universe: cognitive analysis: Monograph. - 2- nd ed. ext. Zaporozhye : Prosvita, 2004. - 148 p.

4. Nikitenko V. O. Problem field geo-cultural phenomenon: naukovi pidhodi / VO Nikitenko // Gileya (Naukova News) : ST. nauk.pr. - K . : ONE type of LLC "NVP" "VIR" . - 2013. Vip.71. - S. 500-504.

НІКІТЕНКО В. О. - кандидат філософських наук, доцент кафедри іноземних мов та лінгвістичної комунікації, Запорізька державна інженерна академія (Запоріжжя, Україна) Еmail: vitalina2006@ukr.net

\section{ФОРМУВАННЯ КУЛЬТУРНО-СОЦАЛЬНОЇ КОМПЕТЕНТНОСТІ У ПРОЦЕСІ ВИВЧЕННЯ АНГЛІЙСЬКОЇ МОВИ: АСПЕКТИ ІНФОРМАЦІЙНОГО СУСПІЛЬСТВА}

У даній статті аналізується іноземна мова та підходи у процесі вивчення соціальних та культурних наук, зокрема, соціальна філософія, політологія, культурологія, психологія, соціологія, історія та інші, які мають ряд одиниць і конструктивних елементів соціальних і гуманітарних наук. Стаття визначає важливість суміснення культурних і геокультурних значень під час вивчення іноземних мов і розкриває їх значення. Кожна з вище означених наук вивчає особливості геокультури, які можуть поглибити наші знання засобами іноземної 
мови, з одного боку, і освоїти іноземну мову за допомогою вказаних дисциплін, з іншого боку.

Ключові слова: іноземна мова, вивчення процесу викладання, підходи, геокультура, лінгвістика, структурний аналіз, мовна характеристика, інформаційне суспільство.

НИКИТЕНКО В. А. - кандидат философских наук, доцент кафедры иностранных языков и лингвистической коммуникации, Запорожская государственная инженерная академия (Запорожье, Украина) E-mail: vitalina2006@ukr.net

\section{СОЗДАНИЕ КУЛЬТУРНОЙ И СОЦИАЛЬНОЙ КОМПЕТЕНТНОСТИ В ПРОЦЕССЕ ИЗУЧЕНИЯ АНГЛИЙСКОГО ЯЗЫКА: АСПЕКТЫ ИНФОРМАЦИОННОГО ОБЩЕСТВА}

В данной статье анализируется иностранный язык и подходы в процессе его изучения методами социальных и культурных наук, в частности, социальная филсоофия, политология, культурология, психология, социология, история и другие, которые имеют ряд единиц и конструктивных элементов социальных и гуманитарных наук. Статья определяет важность совмещения культурных и геокультурных значений во время преподавания иностранного языка, с одной стороны, и освоения инстранного языка при помощи указанных дисциплин, с другой стороны.

Ключяевые слова: иностранный язык, изучение процесса преподавания, подходы, геокультура, лингвистика, структурный анализ, языковая характеристика, информационное общество.

Стаття надійшла до редколегії 11.11.16 p. Рекомендовано до друку 16.11.16 p. 